УДК 347.921 .8

DOI https://doi.org/10.51989/NUL.2021.4.22

\title{
ЮРИДИЧНІ КЛІНІКИ У СИСТЕМІ ПРАКТИЧНОЇ ПІДГОТОВКИ ФАХІВЦІВ У ГАЛУЗІ ПРАВА
}

\author{
Міловська Надія Василівна, \\ доктор юридичних наук, доцент, \\ головний науковий співробітник відділу забезпечення інтеграції академічної \\ та університетської правової науки та розвитку юридичної освіти \\ Київського регіонального центру Національної академії правових наук України
}

У статті досліджено призначення та роль юридичних клінік у системі практичної підготовки фахівців у галузі права, визначено нормативно-правову основу їх організації та діяльності, а також обґрунтовано потребу обов'язкового створення та належного функціонування юридичних клінік у закладах вищої освіти.

Встановлено, що на сьогодні професійна підготовка майбутніх фахівців у галузі права характеризується диспропорцією між теоретичними знаннями та практичними навичками випускників-юристів, що зумовлює складнощі в їх адаптації до практичної роботи. Обґрунтовано, що реформування системи підготовки майбутніх юристів, підвищення ії практичної орієнтованості з урахуванням потреб різних сфер правничої практики, формування навичок правозастосовної діяльності має здійснюватися шляхом залучення студентів до роботи у юридичних клініках, створених у закладах вищої освіти, та стати основою розвитку юридичної освіти в Україні.

Встановлено, що юридичні клініки утворюються з метою закріплення студентами теоретичних знань та набуття ними практичних умінь і навичок професії правника, формування у них поваги до принципів права, підвищення рівня правової культури населення, а також надання безоплатної правової допомоги особам, які їі потребують. При цьому, незважаючи на соціальну складову, освітня мета діяльності юридичних клінік є головною, що зумовлено передумовами зародження самої ідеї використання юридичних клінік у навчальному процесі підготовки юристів.

Підкреслена необхідність урахування прогресивного іноземного досвіду в сфері функціонування юридичних клінік з метою оптимізації їхної діяльності в Україні. Зроблено висновок, що широке впровадження правничими школами України елементів правничої клінічної освіти в навчальний процес та належне використання юридичних клінік як унікальних баз проходження практики студентами-правниками неодмінно сприятиме належній підготовці фахівців у галузі права, формуванню у них стійких практичних навичок правозастосовної діяльності, підвищенню якості юридичної освіти.

Ключові слова: юридична клінічна освіта, професійна підготовка юристів, компетентності правника, практичні навички, правова допомога.

\section{Milovska Nadiia. Legal clinics in the system of practical training of law professionals}

In the article the purpose and role of legal clinics in the system of practical training of specialists in the field of law are researched, the regulatory framework for their organization and activities is defined, and also the need for the mandatory establishment and proper functioning of legal clinics in higher education institutions is substantiated.

It is established that today the professional training of future specialists in the field of law is characterized by a disproportion between theoretical knowledge and practical skills of law graduates, which leads to difficulties in their adaptation to practical work. It is substantiated that reforming the system of training future lawyers, increasing its practical orientation, taking into account the needs of different areas of legal practice, the formation of law enforcement skills should be carried out by attracting students to work in legal clinics established in higher education institutions, and should be become the basis for the development of legal education in Ukraine.

It is established that legal clinics are formed with the aim of consolidating students' theoretical knowledge and acquiring practical skills and abilities of the legal profession, forming their respect for the principles of law, raising the level of legal culture of the population, as 
well as providing free legal assistance to people in need. At the same time, despite the social component, the educational purpose of the activity of legal clinics is the main one, which is due to the prerequisites for the emergence of the very idea of using legal clinics in the educational process of training lawyers.

Attention is focused on the need to take into account the progressive foreign experience in the field of the functioning of legal clinics in order to optimize their activities in Ukraine. It is concluded that the widespread introduction of elements of legal clinical education by the legal schools of Ukraine into the educational process and the proper use of legal clinics as unique bases for passing practice by law students will certainly contribute to the proper training of specialists in the field of law, the formation of their sustainable practical skills in law enforcement, and quality improvement legal education.

Key words: legal clinical education, professional training of lawyers, lawyer's competences, practical skills, legal assistance.

В умовах трансформаційних процесів, що відбуваються сьогодні в українському суспільстві, особливої актуальності набуває проблема модернізації системи юридичної освіти, у якій підготовка висококваліфікованих практикуючих фахівців у галузі права $є$ однією із найважливіших запорук успіху при побудові правової держави в Україні, гуманізації суспільноекономічних відносин, формування нових життєвих орієнтирів особистості.

Відповідно до п. 5 ч. 1 ст. 1 Закону України «Про вищу освіту» [1], вища освіта являє собою сукупність систематизованих знань, умінь і практичних навичок, способів мислення, професійних, світоглядних і громадянських якостей, морально-етичних цінностей, інших компетентностей, здобутих у вищому навчальному закладі (науковій установі) у відповідній галузі знань за певною кваліфікацією на рівнях вищої освіти, що за складністю $є$ вищими, ніж рівень повної загальної середньої освіти. У свою чергу, фундаментом юридичної професії та запорукою професійної компетентності правника $€$ юридична освіта, в якій практична підготовка студентів $\epsilon$ обов'язковим компонентом освітньо-професійної програми для здобуття освітнього ступеня [2, с. 117]. Так, згідно зі Стандартом вищої освіти за спеціальністю 081 «Право» для першого (бакалаврського) рівня вищої освіти, затвердженого наказом Міністерства освіти і науки України № 1379 від 12 грудня 2018 р. [3], до загальних компетентностей випускника правничих спеціальностей належать, серед іншого, здатність застосовувати знання у професійній діяльності у стандартних та окремих нестандартних ситуаціях, вміння працювати як само- стійно, так і в команді колег за фахом. У свою чергу, до спеціальних (фахових, предметних) компетентностей у галузі права за стандартом належать, зокрема, уміння застосовувати знання у практичній діяльності при моделюванні правових ситуацій, навички логічного, критичного і системного аналізу документів, консультування з правових питань.

Занурення у конкретну професійну реальність стає важливим досвідом на шляху здобуття вищої юридичної освіти. Однак на сьогодні в Україні існують деякі проблеми щодо практичної підготовки майбутніх юристів, спричинені насамперед специфікою організації системи юридичної освіти, особливостями визнання їхньої професійної «придатності» до практичної роботи, а також низьким рівнем взаємодії навчальних закладів із роботодавцями. Проблема професійної підготовки майбутніх юристів виявляється у диспропорції між теоретичною та практичною базами на користь першої, тоді як усе більше цінуються саме практичні навички, і все складнішою стає адаптація випускника-юриста до практичної роботи. На думку експертів, головною проблемою юридичної освіти $\epsilon$ невідповідність знань та вмінь випускників юридичних факультетів і закладів вищої освіти вимогам ринку юридичних послуг, основною потребою якого сьогодні $\epsilon$ наявність глибоких спеціальних юридичних знань та професійних компетентностей [4].

Одним із ефективних засобів розв'язання зазначених проблем щодо забезпечення практичної спрямованості юридичної освіти та формування у майбутніх юристів практичних навичок правозастосовної діяльності $\epsilon$ залучення студентів до 
роботи у юридичних клініках, створених у закладах вищої освіти, а також запозичення прогресивного іноземного досвіду в цій сфері.

Аналіз останніх досліджень і публікацій свідчить про постійну увагу до питання юридичної освіти з точки зору визначення іï функцій та основних завдань. Питанням розвитку юридичної клінічної освіти та підготовки фахових правників присвятили праці такі науковці, як А.О. Галай, Н.С. Дубчак, О.С. Клименко, М.А. Котирба, М.Т. Лоджук, Ю.М. Савелова, О.Л. Соколенко, В.В. Стаднік, Ю.О. Фігель, та інші вчені. Водночас, з урахуванням тісного взаємозв'язку правничої теорії і практики, їхнього впливу на формування професійної культури носіїв правничої професії, подальшого наукового вивчення потребує питання значення юридичних клінік у процесі фахової підготовки майбутніх юристів.

Мета статті - визначення ролі та основних завдань юридичних клінік у системі практичної підготовки фахівців у галузі права, нормативно-правової основи їхньої організації та діяльності, а також обґрунтування потреби обов'язкового створення та належного функціонування юридичних клінік у закладах вищої освіти.

Сучасна юридична освіта в Україні належить до традиційної моделі навчання юристів, яка складається з двох взаємопов'язаних частин - теоретичної (включає лекції та семінарські заняття) та практичної (як правило, це ознайомча, виробнича та переддипломна практики). Водночас важливе значення у підготовці майбутніх юристів відіграють юридичні клініки як особливий механізм сприяння підвищенню якості юридичної освіти, що проявляється у створенні для студентів можливості практикуватись в правничій професії під час навчання, виконуючи аналітичну, правозахисну і представницьку функції.

Юридичні клініки - основна організаційна форма правничої клінічної освіти, зміст якої полягає у створенні у структурі юридичного закладу вищої освіти/юридичного факультету штатного чи позаштатного навчально-практичного підрозділу, основною метою діяльності якого $є$ набуття студентами практичних умінь і навичок з надання реальної правничої допомоги найменш забезпеченим верствам насе- лення. У широкому розумінні це поняття підлягає застосуванню до будь-якого типу експериментального, практичного інтерактивного навчання правника, яке включає оволодіння великою кількістю навичок і виховання якостей фахівця, пов'язаних із розвитком професіоналізму [5, с. 2-3].

3 огляду на історію створення та розвитку юридичних клінік, які в Україні у закладах вищої освіти почали працювати наприкінці 90-х рр. минулого століття, їх призначення полягає у досягненні двох основних цілей: 1) освітньої, тобто набуття студентами практичних професійних навичок у процесі надання правничої допомоги: аналізу конкретних життєвих ситуацій і правових відносин на підставі законодавчих та нормативно-правових актів; консультування клієнтів; підготовки правових висновків, процесуальних документів та рекомендацій; представництва інтересів особи перед іншими особами, органами державної влади, та місцевого самоврядування, та 2) соціальної надання правничої допомоги на безоплатній основі тим, хто не в змозі звернутись за отриманням платних юридичних послуг. При цьому, освітня мета діяльності юридичних клінік $\epsilon$ основною, що зумовлено причинами зародження самої ідеї їх виникнення і застосування клінічної практики у процесі навчання майбутніх юристів.

Юридична клініка, здійснюючи навчальну функцію, є прекрасним інструментом для набуття студентами практичних навичок та закріплення теоретичних знань через надання правової допомоги, однак лише за тими категоріями справ, які становлять навчальний інтерес для студентів. Так, у проєкті Концепції розвитку юридичної освіти [6] передбачається необхідність поєднання навчання здобувачів вищої юридичної освіти з діяльністю в юридичних клініках, для чого правничі школи мають сприяти їхньому розвитку у вигляді окремих структурних підрозділів закладів вищої освіти та впровадженню в освітній процес навчальних курсів з правничої клінічної практики.

На сьогодні правове регулювання діяльності юридичних клінік в Україні здійснюється на трьох основних рівнях: загальнодержавному, корпоративному та локальному. Так, загальнодержавний 
рівень представлений вказівкою на юридичні клініки у переліку можливих структурних підрозділів закладу вищої освіти, передбачених ч. 7 ст. 33 Закону України «Про вищу освіту», що свідчить про їх визнання на державному рівні [7, с. 35], та наказом Міністерства освіти і науки України від 3 серпня 2006 р. № 592 «Про затвердження Типового положення про юридичну клініку вищого навчального закладу України» [8].

Корпоративне регулювання, що здійснюється Асоціацією юридичних клінік України як представницьким органом значної більшості існуючих сьогодні юридичних клінік, має значний обсяг нормативного матеріалу, спрямованого на забезпечення, уніфікацію діяльності юридичних клінік та на їхнє відмежування від інших форм об'єднань студентів та молодих юристів, які надають безоплатну правову допомогу (Стандарти діяльності юридичних клінік України, Етичний кодекс діяльності юридичної клініки в Україні). Так, Стандарти діяльності юридичних клінік України, схвалені Асоціацією юридичних клінік України від 19 червня 2014 р. [9], визначають мінімальні вимоги до моделі організаційної структури юридичної клініки закладу вищої освіти України, характеризують організацію її діяльності, навчального процесу з метою підготовки студентів до практичної діяльності, доступу студентів-правників до практики під час навчання, своєчасного надання в необхідному обсязі якісної безоплатної правової допомоги, організації та проведення правоосвітньої роботи. Дотримання цих Стандартів $\epsilon$ вимогою для юридичних клінік членів Асоціації юридичних клінік України, однак вони можуть добровільно використовуватись юридичними клініками, які не входять до Асоціації.

Локальний рівень правового регулювання діяльності юридичних клінік сконцентрований виключно у правничих школах та представлений внутрішніми актами закладів вищої освіти з організації роботи підпорядкованих їм юридичних клінік [10, с. 52]. До таких актів належать установчі документи (статут освітньої установи, положення про юридичну клініку, посадові інструкції співробітників, листи про співпрацю, регламент чи порядок роботи тощо), організаційні документи (план роботи на короткостроковий та довгостроковий періоди, журнал вхідної та вихідної документації, книга відгуків про діяльність тощо) та документи, які готуються у процесі надання правової допомоги (вхідна анкета відвідувача, консультаційна справа чи консультаційний файл, правова довідка, правовий висновок, інші документи правового характеру) [11, c. 10].

Зважаючи на те, що основним завданням юридичної клініки $\epsilon$ набуття студентами практичних навичок професії правника у процесі надання безоплатної правової допомоги, юридичну клініку сьогодні розуміють як структурний підрозділ закладу вищої освіти України, що здійснює підготовку фахівців у галузі знань за напрямом «Право» та функціонує як матеріально-технічна і методична база для практичного навчання та виробничої практики студентів шляхом надання ними безоплатної правничої допомоги та здійснення правопросвітньої діяльності в суспільстві [11, с. 4]. При цьому така організаційно-правова форма функціонування юридичної клініки, як структурний навчально-практичний підрозділ закладу вищої освіти, вважається найбільш оптимальною та такою, що відповідає змісту Закону України «Про вищу освіту», Типового положення про юридичну клініку вищого навчального закладу України, Стандартів діяльності юридичних клінік України та покладає на заклад вищої освіти зобов'язання передбачати такий підрозділ в установчих документах та організаційно-штатному розписі.

Основними принципами діяльності юридичних клінік, які визначають особливості їхнього правового статусу та $\epsilon$ характерними для юридичної клініки як суб'єкта надання безоплатної правової допомоги, $€$ : рівноправність студентів під час діяльності в юридичній клініці; інформування відвідувачів юридичної клініки про правила роботи та особливості надання безоплатної правової допомоги; звітність студентів-консультантів перед керівництвом юридичної клініки; нагляд за якістю правових послуг в юридичній клініці з боку кураторів; відповідальність кураторів 
юридичної клініки за надану студентамиклініцистами некваліфіковану правову допомогу; безоплатність надання правової допомоги; конфіденційність; компетентність та сумлінність [11, с. 13].

Набуття професійних умінь та навичок у юридичних клініках організовується викладачами спільно з практикуючими правниками та може здійснюватися без відриву від навчального процесу. Беручи участь у діяльності клініки, студенти-клініцисти здійснюють прийом відвідувачів/клієнтів та надають їм правову інформацію, консультації та роз'яснення з правничих питань, складають проєкти процесуальних та інших документів правового характеру, здійснюють представництво інтересів осіб у органах державної влади та місцевого самоврядування, перед іншими особами $[10$, с. 26]. Крім того, враховуючи, що консультації клієнту у юридичній клініці надаються саме студентами, то найбільш оптимальною формою їх надання $\epsilon$ винятково письмова форма, що передбачена Стандартами діяльності юридичних клінік України. Надання консультацій у письмовій формі має велике прикладне значення для майбутніх правників. Готуючи письмові консультації, студенти-консультанти отримують практичний досвід підготовки різних правових документів. Крім того, в процесі підготовки письмових правових консультативних висновків студенти-консультанти юридичної клініки набувають практичних умінь та навичок щодо правильної правової кваліфікації фактичних обставин справи. Така робота, як правило, доручається студентам старших курсів закладу вищої освіти. У свою чергу, підбір необхідних нормативних джерел інформації, технічне опрацювання документів та інші види робіт можуть здійснюватись студентами 2-3 років навчання. Крім того, студенти-клініцисти молодших курсів можуть бути залучені до підготовки та проведення просвітницьких занять у загальноосвітніх школах, серед студентів інших факультетів університету, у соціальних та інших закладах. Своєю чергою, викладачі-куратори юридичної клініки орієнтують студентів-консультантів на вирішення конкретних завдань та перевіряють підготовлені тексти правових консультацій/ висновків, допомагають у розробці пра- вопросвітніх занять, проводять додаткові заняття зі слухачами і студентами юридичної клініки, здійснюють керівництво проходження ними навчальної/виробничої практики [12].

Основними умовами забезпечення надання кваліфікованої (якісної) правової допомоги на базі юридичної клініки $\epsilon$ дотримання професійних стандартів та етичних норм під час надання такої допомоги, наявність професійного контролю за її наданням, незалежність надання правової допомоги від впливу третіх осіб, а також додержання принципу конфіденційності під час надання правової допомоги. Питання належного рівня компетенції працівників юридичної клініки стосується також і викладачів-кураторів, адже персонал клініки повинен бути професійним [10, с. 106]. У даному контексті важливо зазначити, що основним компонентом підготовки персоналу юридичної клініки $\epsilon$ спецкурс з правничої клінічної освіти, який має на меті комплексно вирішити проблему поєднання навчання у вищій школі і формування професійної майстерності правника. Програма такого спецкурсу затверджена, зокрема, у Стандартах діяльності юридичних клінік України.

Правнича клінічна освіта як форма професійного навчання студентів правничих спеціальностей, що реалізована на базі юридичних клінік, спрямована на заповнення прогалини, що виникає між отриманими теоретичними знаннями та практикою їх застосування, сприяючи студентам у формуванні в них умінь і навичок правозастосування. У порівнянні $з$ іншими методами і способами підготовки правників, правнича клінічна освіта передбачає: поєднання теоретичного навчання з отриманням практичних навичок; проведення спеціальних занять в юридичній клініці для підготовки студентів до практичної діяльності; навчання студентів викладачами, що мають досвід практичної роботи; розвиток професійних якостей та правової культури; можливість постійного контакту з викладачами при виникненні будь-яких спірних питань у практичній діяльності; використання інтерактивних методів навчання; постійний обмін досвідом організації правничої клінічної освіти між юридичними клініками [12]. Крім цього, 
правнича клінічна освіта володіє системою клінічних методів навчання, що своїм поєднанням дають змогу набути практичних умінь та навичок інтерв'ювання і консультування клієнта, розуміння та аналізу правових ситуацій, напрацювання правових позицій, публічної презентації такої позиції та участі у дебатах, застосовувати поліваріантність вирішення правового спору з позиції етики та врахування очікувань клієнта.

Важливими питаннями подальшого розвитку правничої клінічної освіти в Україні $\epsilon$ створення експериментальної програми з медіації, яка 6 передбачала навчання студентів-консультантів юридичних клінік практиці (навичкам) проведення медіації фахівцями-медіаторами, а також проблема спеціалізації юридичних клінік, перевагами якої, зважаючи на іноземний досвід [13; 14], є надана студентам можливість заздалегідь обирати напрям роботи юридичної клініки, забезпечення більш високого професійного рівня правової допомоги, а також створення більших можливостей для контролю викладачами за діяльністю студентів-консультантів.

Отже, розвиток юридичної освіти в Україні шляхом реформування системи підготовки правників має зосереджува- тись на підвищенні ії̈ практичної орієнтованості з урахуванням прогнозів державних потреб правничих кадрів різних освітніх рівнів. При цьому подолання істотного розриву між юридичною освітою і соціальною практикою повинно здійснюватися на основі компетентнісної моделі підготовки юристів, відповідно до потреб різних сфер правничої практики.

Важливим напрямком підвищення рівня практичної підготовки фахівців у галузі права має стати запровадження та активізація діяльності юридичних клінік у закладах вищої освіти, як бази для практичного навчання, проведення навчальної та інших видів практики студентів шляхом їх безпосереднього залучення до надання безоплатної правової допомоги населенню, що надасть можливість майбутнім юристам безпосередньо застосовувати та засвоювати здобуті знання у всіх сферах юридичної практики та навчитися орієнтуватися у юридичній професії. Широке впровадження правничими школами України елементів правничої клінічної освіти в навчальний процес та належне використання юридичних клінік як унікальних баз проходження практики студентами-правниками неодмінно сприятиме підвищенню якості юридичної освіти.

\section{ЛITЕРАТУРA:}

1. Закон України «Про вищу освіту» від 1 липня 2014 р. № 1556-VII. Відомості Верховної Ради України. 2014. № 37-38. Ст. 2004.

2. Kot, O.O., Milovska, N.V., Yefimenko, L.V. Methodological foundations of legal education reform in Ukraine: Scientific paradigm and modern context. Journal of the National Academy of Legal Sciences of Ukraine. 2021. 28 (2). P. 114-122.

3. Стандарт вищої освіти за спеціальністю 081 «Право» для першого (бакалаврського) рівня вищої освіти, затверджений наказом Міністерства освіти і науки України від 12 грудня 2018 р. № 1379. URL: https://mon.gov.ua/storage/app/media/vishchaosvita/zatverdzeni\%20standarty/12/21/ 081-pravo-bakalavr.pdf (дата звернення: 2 серпня 2021 p.)

4. Звіт за результатами аналітичного дослідження «Знання та навички випускників юридичних факультетів та закладів вищої освіти через призму відповідності потребам ринку праці». URL: https://uba.ua/documents/ZVIT_.Jurosvita.pdf (дата звернення: 2 серпня 2021 р.)

5. Галай А.О., Іваніщ Я.В. Педагогічна характеристика юридичної клінічної освіти. Вісник Асоціації юридичних клінік України. 2005. № 2. С. 2-3.

6. Проект Концепції розвитку юридичної освіти. URL: https://mon.gov.ua/ua/osvita/ visha-osvita/koncepciyavdoskonalennya-pravnichoyi-yuridichnoyi-osviti-dlya-fahovoyipidgotovki-pravnika (дата звернення: 2 серпня 2021 р.)

7. Давлатов Ш.Б. Роль, завдання та організаційно-правові засади юридичних клінік. Правова позиція. 2016. № 1 (16). С. 35. 
8. Типове положення про юридичну клініку вищого навчального закладу України, затверджене наказом Міністерства освіти і науки України від 3 серпня 2006 р. № 592. URL: http://zakon2.rada.gov.ua/laws (дата звернення: 2 серпня 2021 р.)

9. Стандарти діяльності юридичних клінік України. URL: https://legalclinics.in.ua/standarty-diyalnostiyurydychnyh-klinik-ukrayiny/ (дата звернення: 2 серпня 2021 р.)

10. Правнича клінічна освіта в Україні : навчальний посібник/ за заг. ред. В.М. Сущенка. Київ : Ваіте, 2020. 274 с.

11. Лоджук М.Т. Правове регулювання діяльності юридичних клінік в Україні: загальнотеоретичне дослідження: автореф. дис. ... канд. юрид. наук : 12.00.01. Одеса, 2014. 22 c.

12. Фігель Ю.О. Роль юридичних клінік у формуванні вмінь реалізації права студентами юридичних спеціальностей: дис. ... канд.. юрид. наук: 12.00.01. Львів, 2011.

13. Pacific McGeorge Legal Clinics. URL: http://www.mcgeorge. edu/Students/Academics/Experiential_Learning/Legal_Clinics.Htm (дата звернення: 2 серпня 2021 р.)

14. Cardiff Law School Law Clinic - Law in the Real World. URL: http://www.law.cf.ac.uk/ probono (дата звернення: 2 серпня 2021 р.) 